FACTA UNIVERSITATIS

Series: Physical Education and Sport, Vol. 18, No 1, 2020, pp. 197 - 206

https://doi.org/10.22190/FUPES200407017P

Research article

\title{
THE RELATIONSHIP BETWEEN SPECIFIC MOTOR SKILLS AND PERFORMANCE SUCCESS IN FOOTBALL PLAYERS
}

\author{
UDC 796.323.012
}

\author{
Adem Preljević ${ }^{1}$, Omer Špirtović ${ }^{1}$, \\ Damir Ahmić ${ }^{2}$, Lazar Toskić ${ }^{3}$, Armin Zećirović ${ }^{1}$ \\ ${ }^{1}$ Department of Biochemical Science and Sport, State University in Novi Pazar, Novi Pazar, \\ Serbia \\ ${ }^{2}$ University of Travnik, Faculty of Education, Travnik, Bosnia and Herzegovina \\ ${ }^{3}$ Faculty of Sport and Physical Education, University of Priština, Leposavić, Serbia
}

\begin{abstract}
The main aim of this research was to determine to which degree the system of variables used to evaluate specific motor skills correlated with the system of variables used to evaluate successful performance in football play. The study was conducted on a sample of 170 senior football players. There were 16 predictor variables to assess specific motor skills and eight criterion variables to assess successful performance. A canonical correlation analysis was applied in the statistical procedure to determine the relationships (correlations) between these spaces. Correlations were established between the investigated spaces with four pairs of canonical factors, and it has been shown that situational motor skills have high correlations with performance success in the game of football (Can $R .=0.71$, on average). It is indicated that the participants whose performance in football play was more successful also had better situational motor skills and that the mechanism for structuring movement is shown to be of great importance for the successful performance of tactical and technical elements in football players.
\end{abstract}

Key words: Situational Motor Skills, Performance Success, Football Players

\section{INTRODUCTION}

Football is a sport game characterized by numerous complex movements (running, kicking, dribbling, jumping, or falling). The game is also distinguished by a wide variety of technical elements, tactical approaches, whole-body movements, changes in strength

Received April 7, 2020/ Accepted May 11, 2020

Corresponding author: Lazar Toskić

Faculty of Sport and Physical Education, University of Priština, Dositeja Obradovića bb, 38218 Leposavić, Serbia

Phone: + $3812884701 \cdot$ E-mail: lazar.toskic@pr.ac.rs

() 2020 by University of Niš, Serbia | Creative Commons License: CC BY-NC-ND 
and tempo, all adding to its variability and unpredictability (Nicholas, Nuttal, \& Williams 2000; Wragg, Maxwell, \& Doust, 2000; Barron, 2017).

Defeating the opponent requires cooperation of all the team players, who coordinate their spatial and temporal actions with both those of the opponent and the movement of the ball. Due to the speed at which the game is played, its duration, the complexity of the movement involved, the external conditions, and the active interference of the opponent in the efforts to achieve a more favorable result, it is necessary for the player to possess a high level of motor skills (Ostojić, 2000; Mujika, Santisteban, Impellizzeri, \& Castagna, 2009; Cotte \& Chatard, 2011; Kokštejn, Musalek, Wolanski, Murawska-Cialowicz, \& Stastny, 2019). It is estimated that during a match, $80-90 \%$ of the football players' performance is of low to moderate intensity, while the remaining 10-20\% accounts for high intensity (D'ottavio \& Castagna, 2001; Di Salvo, Gregson, Atkinson, Tordoff, \& Drust, 2009; Carling, Le Gall, \& Dupont, 2012). In the course of the match, players perform over 1000 different activities, such as breaking into an easy run from a standing position, passing the ball, or changing the direction of movement with or without the ball (Dellal, Wong, Moalla, \& Chamari, 2010; Bradley et al., 2011).

Among the factors that significantly influence the success in football, situational motor skills take a special place (Bajrić, Lolić, Lolić, \& Bajrić, 2009). In order to form such players in the training process, coaches use various competitive, general and specific exercises, which can be more or less effective. Situational training models that bring football players closer to the conditions of actual play on the pitch occupy a special place in the programming of the training process (Sporiš, Ružić, \& Leko, 2008). Since there are position-specific differences in football players that correspond to different tasks in the game, the training program should include the specifics of the tasks for each position on the team (Javier, 2007). Football players, regardless of age, have a different level of technical and tactical knowledge (Sporiš, Jukić, Ostojić \& Milanović, 2009), while the level of development of their basic and specific motor skills can serve as a criterion for directing young players to a particular position on the team (Bloomfield, Polman, \& O'Donoghue, 2004, Jukić et al., 2019).

A football team functions as a particular cooperative system with 11 players acting as a personal communication network, whose modus operandi primarily depends on which team is in the possession of the ball. When a team has the ball, the main channel of communication marks the attack phase and is identified as a type of cooperative construction. The second communication network parries the first with interference and cooperative destruction, which marks the defense phase. Duel play, involving pushes, collisions, falls and blows, are typical of modern football and specifically require of a player to possess high frustration tolerance, controlled aggression, absence of anxiety, insensitivity to pain, self-dominance, stress resistance, explosive power, restraint in emotions, ability to concentrate, as well as a strong locomotor structure (Junge et al., 2000; Filaire, Lac, \& Pequignot, 2003; Buchheit \& Mendez-Villanueva, 2013; Buchheit et al., 2014; Kocić, Joksimović, \& Stevanović, 2016).

The relationship between motor and situational motor skills in football players and the performance success in football play has not been extensively studied. Accordingly, the aim of this research was to determine to which degree the system of variables used to evaluate specific motor skills correlated with the variables used to evaluate successful performance in football play. It is hypothesized that specific motor skills have a significant correlation with success in football. The results of this study could lead to information about factors that affect performance success in football which could further contribute to the development of training technology and selection process in football. 


\section{METHODS}

\section{Participants}

The study was conducted on a sample of 170 senior football players in the second and third Montenegrin football leagues (Body height $=175.2 \pm 5.1 \mathrm{~cm}$, Body mass $=81.1 \pm 3.5 \mathrm{~kg}$, age $=23.4 \pm 4.3$ years). All participants were healthy, rested and did not have any injuries. The participants had voluntarily agreed to participate in the research by signing an institutionally approved informed consent document. All of the testing was done in accordance with the Declaration of Helsinki.

\section{Procedures}

All situational motor tests were performed on an outdoor turf pitch, and the participants were measured by the same group of instructors, previously trained physical education teachers. The tests and the rest periods were scheduled so that the performance of a task in one test had a minimal impact on the results of any subsequent tests in order to prevent any fatigue effect.

In order to evaluate performance success, that is, the football players' efficiency, a conventional expert panel was used, comprising five judges who were licensed coaches or referees with at least five years' experience of playing for a football club. Each judge gave an independent subjective assessment of the players' performance of technical and tactical skills in the game, their level of physical fitness, engagement in attack and defense, behavior and dedication. The judges' grades ranged from 1 to 5 and were awarded in three championship matches. All tests were performed according to similar previous studies (Gabrijelić, Jerkovič, Aubreont, \& Elzner, 1982).

\section{The sample of variables}

Sixteen tests were selected as the measuring instruments to assess situational motor abilities:

- distance leg kick strength - DLKS (m);

- jumping leg kick strength - JLKS (m);

- distance head kick - DHK (m);

- jumping head kick strength - JHKS (m);

- rectilinear leg kick accuracy - vertical target - RLKA (n);

- elevation leg kick accuracy - horizontal 20 m target - ELKA20 (n);

- volley kick - VK (n);

- header shot - vertical target - HS (n);

- elevation header shot - horizontal target - EHS (n);

- horizontal $20 \mathrm{~s}$ wall rebound - H20 (n);

- surface-to-wall rebound - SWR (n);

- ball advance speed - slalom - BAS1 (s);

- ball advance speed - in a semicircle - BAS2 (s);

- ball advance speed - at a right angle - BAS3 (s);

- ball advance speed - 20 m from a standing start - BAS4 (s);

- leg juggle - LJ (n). 
A system of eight variables was applied to evaluate successful performance in football:

- success in technique performance - ST (n);

- success in the attacking phase of play - SA (n);

- success in the defensive phase of play - SD (n);

- individual creativity - IC (n);

- team responsibility - TR (n);

- engagement - EG (n);

- behavior - BH (n);

- overall success in the performance in play - OS (n).

\section{Statistical analyses}

In data processing, descriptive statistics were used to describe the measured variables, and a canonical correlation analysis was applied in order to determine the relationships and obtain maximum correlations between the analyzed spaces, i.e. between the system of specific motor variables and the system of variables used to evaluate successful performance in football play. In accordance with this method, normalization of variables was performed, and in- and between-group correlations were established for the two groups of variables. Canonical correlations between canonical factor pairs were calculated, and their significance was tested by Bartlett's $\chi^{2}$ test with a marginal error of $.05 \%$.

\section{RESULTS}

Tables 1 and 2 present descriptive values of measured specific motor skills of football players and their performance success in football. It can be noticed that from the aspect

Table 1 Descriptive statistics - specific motor skills

\begin{tabular}{lccccc}
\hline & Mean & SD & cV & Min & Max \\
\hline DLKS (m) & 51.32 & 10.13 & 19.74 & 39.48 & 68.64 \\
JLKS (m) & 20.04 & 5.28 & 26.35 & 14.52 & 28.55 \\
DHK (m) & 4.96 & 0.63 & 12.70 & 2.84 & 6.37 \\
JHKS (m) & 6.25 & 0.58 & 9.28 & 3.32 & 10.12 \\
RLKA (n) & 10.35 & 3.48 & 33.62 & 3 & 16 \\
ELKA20 (n) & 6.21 & 4.13 & 66.51 & 1 & 20 \\
VK (n) & 3.46 & 1.74 & 50.29 & 1 & 7 \\
HS (n) & 14.72 & 4.8 & 32.61 & 2 & 15 \\
EHS (n) & 4.52 & 1.8 & 39.82 & 0 & 12 \\
H20 (n) & 5.86 & 2.7 & 46.08 & 1 & 13 \\
SWR (n) & 4.21 & 1.5 & 35.63 & 1 & 11 \\
BAS1 (s) & 18.37 & 1.98 & 10.78 & 12.63 & 28.57 \\
BAS2 (s) & 14.57 & 1.64 & 11.26 & 11.48 & 25.83 \\
BAS3 (s) & 15.54 & 1.88 & 12.10 & 12.97 & 26.41 \\
BAS4 (s) & 15.36 & 2.05 & 13.35 & 11.41 & 22.36 \\
LJ (n) & 42.3 & 15.8 & 37.35 & 21 & 79 \\
\hline
\end{tabular}

Legend: DLKS - distance leg kick strength, JLKS - jumping leg kick strength, DHK - distance head kick, JHKS - jumping head kick strength, RLKA - rectilinear leg kick accuracy - vertical target, ELKA20 elevation leg kick accuracy - horizontal $20 \mathrm{~m}$ target, VK - volley kick, HS - header shot - vertical target, EHS

- elevation header shot - horizontal target, H20 - horizontal $20 \mathrm{~s}$ wall rebound, SWR - surface-to-wall rebound, BAS1 - ball advance speed - slalom, BAS2 - ball advance speed - in a semicircle, BAS3 - ball advance speed - at a right angle, BAS4 - ball advance speed - $20 \mathrm{~m}$ from a standing start, LJ - leg juggle. 
of motor skills, football players are the most homogeneous in jumping head kick strength $(\mathrm{cV}=9.28)$, while their results are the least homogenous in the volley kick parameter $(\mathrm{cV}=50.29)$. When it comes to performance success, players are the most homogenous in the team responsibility parameter $(\mathrm{cV}=9.36)$, while they have the lowest homogeneity in the engagement parameter $(\mathrm{cV}=31.40)$.

Table 2 Descriptive statistics - performance success

\begin{tabular}{lccccc}
\hline & Mean & SD & $\mathrm{cV}$ & Min & Max \\
\hline ST & 3.26 & 0.89 & 27.30 & 1 & 5 \\
SA & 2.88 & 0.46 & 15.97 & 1 & 5 \\
SD & 3.41 & 0.52 & 15.25 & 1 & 5 \\
IC & 2.31 & 0.44 & 19.05 & 1 & 5 \\
TR & 3.42 & 0.32 & 9.36 & 2 & 5 \\
EG & 3.28 & 1.03 & 31.40 & 2 & 5 \\
BH & 3.21 & 0.78 & 24.30 & 1 & 5 \\
OS & 2.83 & 0.63 & 22.26 & 1 & 5 \\
\hline \multicolumn{5}{r}{ Legend: ST - success in technique performance, SA - success in the attacking phase of play, } \\
SD - success in the defensive phase of play, IC - individual creativity, TR - team responsibility, \\
\multicolumn{5}{r}{ EG - engagement, BH - behavior, OS - overall success in the performance in play. }
\end{tabular}

The results of determining the association between the specific motor skills and the criterion variables showed that these two spaces exhausted $86 \%$ of the variance of the analyzed system of variables tested by Bartlett's test, amounting to 413.50 , and that there were statistically significant correlations of Can $\mathrm{R} .=0.93$ for the first pair, Can $\mathrm{R}=0.86$ for the second pair, Can R. $=0.83$ for the third pair, and Can R. $=0.74$ for the fourth pair of canonical factors at $\mathrm{p}=0.000$ (Table 3 ).

Table 3 Canonical correlation analysis of the specific motor skills and criterion variables

\begin{tabular}{ccccccc}
\hline Roots & Canl R & Can R\% & Chi-sqr. & df & Lambda & Sig. \\
\hline 0 & 0.93 & 0.86 & 413.50 & 120 & 0.00 & 0.00 \\
1 & 0.86 & 0.75 & 278.40 & 98 & 0.01 & 0.00 \\
2 & 0.83 & 0.69 & 184.89 & 78 & 0.06 & 0.00 \\
3 & 0.74 & 0.55 & 105.96 & 60 & 0.20 & 0.00 \\
\hline
\end{tabular}

The results of the analysis for the situational motor parameters revealed that the first canonical factor was characterized by high correlations with the following variables used to assess situational motor skills (Table 4): elevation leg kick accuracy - horizontal $20 \mathrm{~m}$ target (ELKA20), volley kick (VK), header shot - vertical target (HS), horizontal $20 \mathrm{~s}$ ball rebound (H20), surface-to-wall rebound (SWR), and leg juggle (LJ). The second canonical factor was predominantly defined by the variables used to assess distance head kick (DHK) and ball advance speed at $20 \mathrm{~m}$ (BAS4). The third canonical factor was mainly defined by the variables used to assess distance leg kick strength (DLKS) and jumping leg kick strength (JLKS). The fourth canonical factor was determined by a high correlation of the variable used to evaluate jumping head kick strength (JHKS). 
Table 4 Factor structure of the specific motor skills (left set)

\begin{tabular}{lrrrr}
\hline & CAN1 & CAN2 & CAN3 & CAN4 \\
\hline DLKS & -0.23 & -0.06 & -0.47 & -0.42 \\
JLKS & -0.00 & 0.27 & -0.63 & -0.10 \\
DHK & -0.11 & 0.32 & -0.42 & -0.10 \\
JHKS & -0.07 & 0.25 & -0.16 & -0.50 \\
RLKA & 0.25 & 0.22 & -0.33 & -0.07 \\
ELKA & 0.42 & 0.39 & 0.08 & 0.32 \\
VK & 0.84 & -0.01 & -0.02 & -0.17 \\
HS & 0.46 & 0.14 & -0.08 & -0.10 \\
EHS & 0.29 & 0.06 & 0.02 & -0.15 \\
H20 & 0.81 & 0.01 & -0.22 & -0.27 \\
SWR & 0.74 & 0.05 & -0.29 & -0.38 \\
BAS1 & 0.13 & -0.19 & 0.10 & 0.07 \\
BAS2 & 0.12 & 0.09 & 0.11 & 0.24 \\
BAS3 & 0.23 & 0.30 & 0.12 & -0.06 \\
BAS4 & 0.55 & -0.08 & 0.17 & -0.17 \\
LJ & -0.23 & -0.06 & -0.47 & -0.42 \\
\hline
\end{tabular}

Legend: DLKS - distance leg kick strength, JLKS - jumping leg kick strength, DHK - distance head kick, JHKS - jumping head kick strength, RLKA - rectilinear leg kick accuracy - vertical target,

ELKA20 - elevation leg kick accuracy - horizontal $20 \mathrm{~m}$ target, VK - volley kick, HS - header shot - vertical target, EHS - elevation header shot - horizontal target, H20 - horizontal 20 s wall rebound, SWR - surface-towall rebound, BAS1 - ball advance speed - slalom, BAS2 - ball advance speed - in a semicircle, BAS3 - ball advance speed - at a right angle, BAS4 - ball advance speed - $20 \mathrm{~m}$ from a standing start, $\mathrm{LJ}$ - leg juggle.

The analysis of the canonical factor matrix for the right set of variables revealed that the first isolated canonical factor highly correlated with the following criterion variables used to evaluate successful performance (Table 5): technique (ST), attack (SA), creativity (IC) and overall success (OS). The second canonical factor showed a high correlation with only one variable used to assess successful performance: engagement (EG). The third canonical factor also highly correlated with only one variable in success assessment: responsibility (TR). The analysis of the canonical factor matrix for the right set of variables did not reveal high correlations between the fourth isolated canonical factor and the criterion variables.

Table 5 Factor structure of specific motor skills (right set)

\begin{tabular}{ccccc}
\hline & CAN1 & CAN2 & CAN3 & CAN4 \\
\hline ST & 0.85 & 0.12 & -0.02 & -0.29 \\
SA & 0.68 & 0.21 & -0.46 & -0.48 \\
SD & 0.11 & -0.05 & 0.12 & 0.07 \\
IC & 0.78 & 0.31 & 0.04 & -0.34 \\
TR & 0.04 & 0.19 & -0.33 & -0.27 \\
EG & 0.07 & 0.55 & -0.05 & -0.45 \\
BH & 0.12 & 0.74 & -0.26 & 0.03 \\
OS & 0.53 & 0.34 & -0.44 & 0.03 \\
\hline \multicolumn{5}{c}{ Legend: ST - success in technique performance, } \\
SD - success in the defensive phase of play, IC - individual creativity, \\
TR - team responsibility, EG - engagement, BH - behavior, \\
OS - overall success in the performance in play.
\end{tabular}




\section{DISCUSSION}

This study investigated the relationship between specific motor skills and performance success in football play on a sample of 170 football players. As previously mentioned, the results of this study could lead to information about factors that affect performance success in football which could further contribute to the development of training technology and the selection process in football.

Tables 1 and 2 presents the descriptive values of measured specific motor skills of football players and their performance success in football, which shows that from the aspect of motor skills, football players are the most homogeneous in jumping head kick strength, while their results are the least homogenous in the volley kick parameter. Generally, it can be noticed that these participants have the highest homogeneity on those tests which contain fast distance movements with the ball (BAS1, BAS2, BAS3, BAS4, $\mathrm{cV}=11.8$, on average), that is activities which are familiar to them and which they regularly practice during their training and matches. When it comes to performance success, players are the most homogenous in the team responsibility parameter, while they have the lowest homogeneity in the engagement parameter. This group of football players generally had the lowest grades when it comes to individual creativity (2.31), overall success in the performance in play (2.83) and success in the attack phase of play (2.88), while they had the best results in success in the defense phase of play (3.41) and team responsibility (3.42). These results are somewhat expected. Previous studies showed that lower league football players have lower values of some psychological characteristics (Memmert, Baker, \& Bertsch, 2010; Vestberg, Gustafson, Maurex, Ingvar, \& Petrović, 2012; Danielsen, Rodahl, Giske, \& Høigaard, 2017), and general physical fitness parameters than those from higher leagues (Davis, Brewer, \& Atkin, 1992; Cometti, Maffiuletti, Pousson, Chatard, \& Maffulli, 2001). Since participants involved in this research played in the second and third football league, it can be assumed that they have relatively lower values for the afore mentioned properties, which could lead to low grades when it comes individual creativity, overall success and success in the attack phase.

Based on the results presented in Table 3, it can be concluded that these two spaces, that is motor skills and performance success, exhausted $86 \%$ of the variance of the analyzed system of variables tested by the Bartlett's test, amounting to 413.50, and that there were statistically significant correlations of Can R. $=0.93$ for the first pair, Can R. $=0.86$ for the second pair, Can R. $=0.83$ for the third pair, and Can $\mathrm{R} .=0.74$ for the fourth pair of canonical factors at $\mathrm{p}=0.000$.

The results presented on the Tables 4 and 5, that is, the analysis for the situational motor parameters, revealed that the first canonical factor was characterized by high correlations with the elevation leg kick accuracy - the horizontal $20 \mathrm{~m}$ target (ELKA20), volley kick (VK), header shot - vertical target (HS), horizontal $20 \mathrm{~s}$ ball rebound (H20), surface-to-wall rebound (SWR), and leg juggle (LJ). The second canonical factor was predominantly defined by the variables used to assess the distance head kick (DHK) and ball advance speed at $20 \mathrm{~m}$ (BAS4), and can be defined as the canonical dimension of head kick strength and rectilinear ball advance speed. The third canonical factor was mainly defined by the variables used to assess distance leg kick strength (DLKS) and jumping leg kick strength (JLKS), and can be defined as the canonical dimension of leg kick strength, while the fourth canonical factor was determined by a high correlation of the variable used to evaluate jumping head kick strength (JHKS). The analysis of the canonical factor matrix for the right 
set of variables revealed that the first isolated canonical factor highly correlated with the variables used to evaluate successful performance (Table 5): technique (ST), attack (SA), creativity (IC) and overall success (OS). It can be defined as the general canonical factor of success in football play. The second canonical factor showed a high correlation with only one variable used to assess successful performance: engagement (EG). It can be defined as the canonical factor of engagement in football play. The third canonical factor also highly correlated with only one variable in success assessment: responsibility (TR). It can be defined as the canonical factor of responsibility in football play. The analysis of the canonical factor matrix for the right set of variables did not reveal high correlations between the fourth isolated canonical factor and the criterion variables.

The relationship between the first pair of canonical factors can be understood as a basic measure of the correlation between these systems. Considering the magnitude of the shared variance between the first pair in the analyzed spaces, it can be argued that the two systems are correlated to a high degree. It has shown that situational motor skills have high correlations with performance success in the game of football. All the variables in either set have a positive sign so that situational motor skill variables can be said to have high canonical factor loadings achieved by the participants who had a better score in leg kick accuracy, volley kick, header shot accuracy, $20 \mathrm{~s}$ ball rebound, surface-to-wall rebound, and leg juggle, and who had a general success factor in football play. This association indicates that the participants whose performance in football play was more successful also had better situational motor skills.

The relationship between the first pair of canonical factors can be interpreted so that the mechanism for structuring movement is shown to be of great importance for the successful performance of tactical and technical elements in football players. The mechanism controlling a variety of coordinated operations is far more complex than the assumption on coordination structure might imply. Coordination is substantially saturated with the dimensions of strength, speed and balance, as many studies suggest. Complex central nervous system structures are of the utmost importance for the rapid execution of elaborate motor tasks. The movement structuring mechanism plays a special role, with the main function to program movement, especially since the performance of tasks requires that the entire body moves in space. The central nervous system manages movement through a system of hierarchical structure, including regulatory mechanisms, which will depend on the complexity of the motor task (Kurelić et al., 1975).

The second, third and fourth pairs of canonical factors cannot be meaningfully interpreted. The variability in the success in the game of football concerning the present sample was affected more by the difference in the learning process than by the relationships among potential skills or characteristics.

\section{CONCLUSION}

Correlations were established between the investigated spaces with four pairs of canonical factors and it was shown that situational motor skills have high correlations with performance success in the game of football. It is indicated that the participants whose performance in football play was more successful also had better situational motor skills and that the mechanism for structuring movement is shown to be of great importance for the 
successful performance of tactical and technical elements in football players.

The results of this study confirmed the fact that football training to a large extent needs to be orientated towards the development of situational motor skills and that football coaches should select those individuals who possess a high level of these properties.

\section{REFERENCES}

Bajrić, O., Lolić, V., Lolić, D., \& Bajrić, S. (2009). Analiza uticaja nekih antropoloških odlika na uspješnost u rešavanju tehničko-taktičkih zadataka u nogometu. Sport Mont, 28-30(9), 386-393.

Barron, D.J. (2017). The derivation and validation of a novel field test for youth soccer. Doctoral dissertation. Preston: University of Central Lancashire.

Bloomfield, J., Polman, R.C.J., \& O'Donoghue, P.G. (2004). Motion analysis of individuals in team sports. International Journal of Performance Analysis of Sport, 4(2), 20-31.

Bradley, P. S., Carling, C., Archer, D., Roberts, J., Dodds, A., Di Mascio, M., et al. (2011). The effect of playing formation on high-intensity running and technical profiles in English FA Premier League soccer matches. Journal of Sports Sciences, 29(8), 821-830.

Buchheit, M., \& Mendez-Villanueva, A. (2013). Supramaximal intermittent running performance in relation to age and locomotor profile in highly-trained young soccer players. Journal of Sports Sciences, 31(13), 1402-1411.

Buchheit, M., Mendez-Villanueva, A., Mayer, N., Jullien, H., Marles, A., Bosquet, L., et al. (2014). Locomotor performance in highly-trained young soccer players: Does body size always matter?. International Journal of Sports Medicine, 35(6), 494-504.

Carling, C., Le Gall, F., \& Dupont, G. (2012). Analysis of repeated high-intensity running performance in professional soccer. Journal of Sports Sciences, 30(4), 325-336.

Cometti, G., Maffiuletti, N. A., Pousson, M., Chatard, J. C., \& Maffulli, N. (2001). Isokinetic strength and anaerobic power of elite, subelite and amateur French soccer players. International Journal of Sports Medicine, 22(1), 45-51.

Cotte, T., \& Chatard, J. C. (2011). Isokinetic strength and sprint times in English premier league football players. Biology of Sport, $28(2), 89$.

Danielsen, L. D., Rodahl, S. E., Giske, R., \& Høigaard, R. (2017). Mental toughness in elite and sub-elite female soccer players. International Journal of Applied Sports Sciences, 29(1), 77-85.

Davis, J. A., Brewer, J., \& Atkin, D. (1992). Pre-season physiological characteristics of English first and second division soccer players. Journal of Sports Sciences, 10(6), 541-547.

Dellal, A., Wong, D. P., Moalla, W., \& Chamari, K. (2010). Physical and technical activity of soccer players in the French First League-with special reference to their playing position. International SportMed Journal, 11(2), 278-290.

Di Salvo, V., Gregson, W., Atkinson, G., Tordoff, P., \& Drust, B. (2009). Analysis of high intensity activity in Premier League soccer. International Journal of Sports Medicine, 30(3), 205-212.

D'ottavio, S., \& Castagna, C. (2001). Analysis of match activities in elite soccer referees during actual match play. The Journal of Strength \& Conditioning Research, 15(2), 167-171.

Filaire, E., Lac, G., \& Pequignot, J. M. (2003). Biological, hormonal, and psychological parameters in professional soccer players throughout a competitive season. Perceptual and Motor Skills, 97(3_suppl), 1061-1072.

Javier, G. (2007). Physiological and anthropometric characteristics of young soccer players according to their playing position: relevance for the selection process. The Journal of Strength and Conditioning Research, 21(2), 438-446.

Jukić, I., Prnjak, K., Zoellner, A., Tufano, J. J., Sekulić, D., \& Salaj, S. (2019). The importance of fundamental motor skills in identifying differences in performance levels of U10 soccer players. Sports, 7(7), 178.

Junge, A., Dvorak, J., Rosch, D., Graf-Baumann, T., Chomiak, J., \& Peterson, L. (2000). Psychological and sport-specific characteristics of football players. The American Journal of Sports Medicine, 28(5), 22-28.

Kocić, M., Joksimović, A., \& Stevanović, M. (2016). Differences in explosive strength of legs between football and futsal players. Facta Universitatis Series Physical Education and Sport, 14(2), 269-278.

Kokštejn, J., Musalek, M., Wolanski, P., Murawska-Cialowicz, E., \& Stastny, P. (2019). Fundamental motor skills mediate the relationship between physical fitness and soccer-specific motor skills in young soccer players. Frontiers in Physiology, 10, 596. 
Kurelić, N., Momirović, K., Stojanović, M., Šturm, J., Radojević, Đ \& Viskić-Štalec, N. (1975). Struktura i razvoj morfoloških i motoričkih dimenzija omladine (Structure and development of morphological and motor dimensions of youth). Belgrade: Institute for Scientific Research, Faculty of Physical Education, University of Belgrade. In Serbian

Memmert, D., Baker, J., \& Bertsch, C. (2010). Play and practice in the development of sport-specific creativity in team ball sports. High Ability Studies, 21(1), 3-18.

Mujika, I., Santisteban, J., Impellizzeri, F. M., \& Castagna, C. (2009). Fitness determinants of success in men's and women's football. Journal of Sports Sciences, 27(2), 107-114.

Nicholas, C.W., Nuttal, F.E., \& Williams C. (2000). The Loughborough Intermittent Shuttle Test: A field test that simulates the activity pattern of soccer. Journal of Sports Sciences 18(2), 97-104.

Ostojić, S.M. (2000). Physical and physiological characteristics of elite Serbian soccer players. Facta Universitatis Series Physical Education and Sport, 1(7), 23-29.

Sporiš, G., Jukić, I., Ostojić, S.M \& Milanović, D. (2009). Fitness profiling in soccer: physical and physiologic characteristics of elite players. The Journal of Strength and Conditioning Research, 23(7), 1947-1953.

Sporiš, G., Ružić, L., \& Leko, G. (2008). The anaerobic endurance of elite soccer players improved after a highintensity training intervention in the 8-week conditioning program. The Journal of Strength \& Conditioning Research, 22(2), 559-566.

Vestberg, T., Gustafson, R., Maurex, L., Ingvar, M., \& Petrović, P. (2012). Executive functions predict the success of top-soccer players. PloS one, 7(4), e34731.

Wragg, C.B., Maxwell, N.S., \& Doust, J.H. (2000) Evaluation of the reliability and validity of a soccer-specific field test of repeated sprint ability. European Journal of Applied Physiology, 83(1), 77-83.

\section{RELACIJE IZMEĐU SITUACIONO-MOTORIČKIH SPOSOBOSTI I USPEŠNOSTI U IGRI FUDBALERA}

Cilj istraživanja je da se utvrdi stepen povezanost sistema variajbli za procenu situacionomotoričkih sposobnosti sa varijabliama za procenu uspešnosti u fudbalskoj igri. Istraživanje je sprovedeno na uzorku od 170 ispitanika, fudbalera - seniora. U istraživanju je primenjeno 16 varijabli za procenu specifčnih motoričkih sposobnosti i osam varijabli za procenu uspešnosti u fudbalskoj igri. Za utvrđivanje povezanosti (relacija) između navedenih prostora primenjena je kanonička korelaciona analiza. Na osnovu dobijenih rezultata, utvrđeno je da su istraživani prostori međusobno povezani sa četiri para kanoničkih faktora, odnosno da situaciono-motoričke sposobnosti imaju visoku povezanost sa uspešnosti u fudbalskoj igri (Can R. =0.71, u proseku). Pokazalo se da ispitanici koji postižu bolje rezultate u uspešnosti u fudbalskoj igri imaju bolje situaciono-motoričke sposobnosti kao $i$ da je za uspešno izvođenje taktičko tehničkih elemenata kod fudbalera od velike važnosti mehanizam za strukturiranje kretanja.

Ključne reči: situaciono-motoričke sposobnosti, uspešnost u igri, fudbaleri 